UDC 811.111:159.925:378.147

DOI https://doi.org/10.32838/2663-6069/2020.1-2/18

Kovalevska O. $V$.

Dnipropetrovsk State University of Internal Affairs

\title{
IMPLEMENTATION OF THE THEORY OF MULTIPLE INTELLIGENCES IN THE PROCESS OF LEARNING ENGLISH TO NON-PHILOLOGICAL UNIVERSITY STUDENTS
}

This paper focuses on the development of new didactic ideas, which are directly related to the development of theoretical linguistics, the philosophy of language. It was found out that nowadays, the philosophy of language has been enriched with new theories that have found application in the practice of learning English language, but the question of choosing the most effective methods is quite relevant today. Attention is paid to implementation of the theory of Multiple Intellingences (MI) in the process of English learning to non-philologal university students. The Multiple Intelligences approach is based on a learning philosophy that treats the inherent intelligence of a person as a set of equivalent intellects that must first be understood and then further developed in the learning process. The use of Multiple Intelligences theory in learning English language makes possible to understand, that language proficiency is improved for all students, and not only for a small part of them. The implementation of the theory of Multiple Intelligences has had a positive impact in learning English for non-philologal university students. The results of summative and formative experiments prove that the application of these methodological developments in the process of English learning will be effective not only for the development of linguistic skills, but also for the formation of professionally significant properties of future specialists.

The Multiple Intelligences theory has received worldwide recognition as one of the most innovative theories of human intelligence. Its properly application in the educational process, in particular in the process of teaching English language will help the students to realize their potential and will be useful for teachers to find innovative approaches of education.

Key words: philosophy of language, non-philologal university, students, Multiple Intelligences theory, English learning process.

Problem statement. One of the most important tasks of modern education is the individualization of the learning process, its orientation on the personality. Knowledge of a foreign language as a means of social communication is an indispensable part of educational development, where a foreign language is considered to be a part of another culture. In this regard, the teacher of a foreign language is tasked to be able to teach how to participate in intercultural communication, and therefore there is a need to create new approaches, technologies and methods of learning a foreign language.

Nowadays, the philosophy of language has been enriched with new theories, that have found application in the practice of teaching foreign languages, but the question of choosing the most effective teaching methods is quite relevant today.

The development of innovative learning approaches is directly related to the development of theoretical linguistics, the philosophy of language. A weak theoretical background leads to a haphazard teaching method that affects the learning process in general.
The relevance of the research topic is determined by theoretical meaning of pedagogical views, and its practical values in identifying methods, forms and conditions for implementation innovative approach in learning English such as Multiple Intelligences theory in a modern higher educational non-philologal institution.

Analysis of studies and publications. The analysis of foreign and domestic psychological, philological and pedagogical literature allows us to identify the contradictions among modern educational reality in the assessment and analysis of the studies enlighten in the works of American scientists H. Gardner. A large amount of literature is dedicated to the principles of different learning styles that require the involvement of various types of intelligence for learning (O. Andropova, N. Antonenko, L. Baysara, M. Gogoleva). The scientific works of H. Gardner such as books and articles served as the main source in the reconstruction and analysis of world's pedagogical views. The use of theoretical works by prominent representatives of Western psychological 
and pedagogical thought (J. Piaget, B. F. Skinner, E. S. Tolman, etc.) allows us to carry out a comparative historical analysis of H. Gardner's views with the main theoretical provisions of other pedagogical schools of the XXth century, to re-create the scientific and ideological environment where he developed as a cognitive scientist.

Objective statement. The objective of this study has been to determine the importance of implementation the innovative approach in learning English such as Multiple Intelligences theory in a modern higher educational non-philologal institution. We need to resolve the contradictions in the research problem, which in theoretical terms consists of revealing the main provisions of $\mathrm{H}$. Gardner's pedagogical views. Our choice is explained by the fact, that in many countries of Europe lots of language teachers are faced with an issue, where large groups of students consist of different levels of knowledge foreign language and different language abilities, that is why the question to find out the most effective methods of learning has had significant meaning nowadays.

Main body. One of the problems that arise in the process of teaching a foreign language, including English, is the need to take into account the individual characteristics of students that are simultaneously present in the lesson. The theory of Multiple Intelligences created by American psychologist Howard Gardner was first published in his book "Frames of Mind" in 1983. Thus, it reveals one of the possible ways of individualization the education process and the most effective way of studying foreign language.

In this regard, we would like to implement the theory of Multiple Intelligences to non-philologal university students in their English learning process.

The experimental study was conducted during a course with the first year students who studied English language. We provided a research with 60 students, and separated them into experimental and control groups. We used a comparative method in order to gain a better understanding about how the Multiple Intelligences theory works. The students in experimental group were tested to identify the leading type of intelligence for each student in order to implement the Multiple Intelligences theory in learning process, where students in control groups were taught by conventional method [3, p. 10-14].

In the study "Frames of Mind", the scientist believes that each person is talented, and also it is emphasized the need to take into account the differences of intelligence in the process of learning. Therefore, according to the theory, it is distinguished seven types of intelligences (Table 1).

Types of Intelligences by H. Gardner

\begin{tabular}{|l|l|}
\hline \multicolumn{1}{|c|}{ Types of Intelligences } & \multicolumn{1}{c|}{ Description } \\
\hline Verbal-linguistic ("word smart") & $\begin{array}{l}\text { Well-developed among students who are easily susceptible to language } \\
\text { and sensitive to the nuances, order and rhythm of words. They love } \\
\text { to read, write and tell stories, have good verbal memory and a rich } \\
\text { vocabulary. }\end{array}$ \\
\hline Logical-mathematical ("number smart") & $\begin{array}{l}\text { People with this type of intelligence possess excellent analytical skills, } \\
\text { think well and ask logical questions. }\end{array}$ \\
\hline Visual-spatial (" picture smart") & $\begin{array}{l}\text { It is found among people who need visual images, they well extract } \\
\text { information from maps, charts, diagrams. They are good at drawing, } \\
\text { plotting, modeling. }\end{array}$ \\
\hline Music-rhythmic ("music smart") & $\begin{array}{l}\text { A person easily remembers melodies and is able to reproduce them. It } \\
\text { is about the ability to perceive music, evaluate it, transform, and create } \\
\text { music and perform it. }\end{array}$ \\
\hline Body-kinesthetic ("body smart") & $\begin{array}{l}\text { Solves the set tasks, creates and conveys ideas and emotions through } \\
\text { the movements of the body. People with such intellect have good } \\
\text { coordination of movements, are very mobile, have developed gestures } \\
\text { and tactile memory. }\end{array}$ \\
\hline Interpersonal ("people smart") & $\begin{array}{l}\text { Refers to the ability to effectively interact with people, understand } \\
\text { them and recognize their goals, motivation and intentions. People with } \\
\text { this type of intelligence are happy to work in cooperation, have good } \\
\text { leadership and diplomatic qualities. }\end{array}$ \\
\hline Intrapersonal ("self-smart") & $\begin{array}{l}\text { Associated with an understanding of one's own emotions, goals } \\
\text { and intentions, appeal to the inner world of a person. Students with } \\
\text { this type of intelligence have a heightened self-esteem, they are self- } \\
\text { confident and love to work alone. They really value their strengths } \\
\text { and abilities. }\end{array}$ \\
\hline
\end{tabular}


It is enlighten in the table, that each type of intelligence manifests itself through specific talents, skills and interests. Besides, later, the researcher added two more types: "natural smart" and existential ("problem solving smart").

Perhaps, the understanding that each of these types of intelligence can be developed among students will have a significant impact on the teaching methods of students and will allow the educational process to be organized so that they learn according to their capabilities and achieve better results. Following the study of E. G. Andropova, we believe that, depending on the dominant type of intelligence of each student, the teacher can choose the set of exercises that will most effectively help the student to learn new material [10, p. 3-9].

According to the $\mathrm{H}$. Gardner's types of intelligences we will try to illustrate how it is possible to develop different types of intelligence in the process of learning English in the experimental group on the basis of grammatical topic "Subjunctive Mood" as an example. Let us consider a set of tasks on the topic "Subjunctive Mood" depending on the type of students' intelligences [11, p. 110-112].

\section{The verbal/linguistic type of intelligence.}

Task: Fill in the blanks. For example: If I__ a police officer, I would

2. The logical/mathematical type of intelligence.

Task: Look at the diagram and formulate the rule.

Type I: Present Real

Dependent Clause Independent Clause

present simple will, can, should, may,

present continuous might, ought to + main verb

present perfect modals: can, have to, must, should

present perfect continuous

3. Visual/spatial type of intelligence.

Prepare a presentation on the theme: "What would I buy if I won one million dollars".

4. The bodily-kinesthetic type of intelligence.

Role-playing game. You are in the USA on vacation. Talk with the friend about your plans for tomorrow. For example: If it rains tomorrow, we can't go to Disney World.

5. The musical or rhythmic type of intelligence.

Learn a song with this grammatical phenomenon. For example:

If I had a hammer, I'd hammer in the morning,

If I had a hammer, I'd hammer at noon.

I'd hammer out justice; I'd hammer our warning

I'd hammer out love between my brothers and my sisters, all over this world.

6. Interpersonal type of intelligence.

Interview students in a group.
Ask "What would you do if you were a teacher / a pilot / a musician?"

\section{Intrapersonal type of intelligence.}

Write a short essay on the topic: "If you could change one thing about yourself, what would it be?"

Educational professionals say that there are two types of evaluating students after the complection of a course. There are testing and assessing. A common belief shared by many educators nowadays is that authentic assessment, which emphasizes assessing what students know (knowledge) and what students do (performance) from different perspectives aims to provide a complete picture of students' abilities, efforts and progress during the learning process [5, p. 124-128]. Moreover, the Multiple Intelligences theory is opposed to the traditional view of education and standardized tests; it opts for multiple approaches of assessment that will allow students to show their strengths for optimal performance. Accordingly, the knowledge assessment of the first year students was conducted in the compulsory English language course (experimental group) to asses the effects of the implementation of the Multiple Intelligences theory.

The results of the experimental work confirmed the assumption that a set of tasks in the English language, selected depending on the dominant type of students' intelligence, helps to effectively absorb new grammatical material. Students in the experimental groups showed results by $24 \%$ higher compared with the students in the control groups.

Besides, during the experiment, academic achievement of the students was improved by $40 \%$ higher. The results of the experiment indicate, that students who were taught in experimental groups by the use of Multiple Intelligences theory developed more than students in control groups. This is due to the fact the Multiple Intelligences based teaching of English is more effective than the conventional method. In addition, it motivates the students to understand the material easier that the traditional way of education recommends.

Moreover, all students developed and applied new skills. At the beginning of the course, only one dominant type of intelligence was shown by most students in experimental group. By the end of the year every student felt confident in such types of activities, that are inherent to students with other types of intelligence. It makes possible to understand, that firstly, non-verbal thinkers become more interested and active in foreign language classes, and they gradually develop their language skills. 
Secondly, language proficiency is improved for all students, and not only for a small part of them, where we consider students well-skilled only because they foreign language teacher has such skills

Working within the framework of Howard Gardner's Theory of Multiple Intelligences, the teacher helps students to carry out joint mental activity [13, p. 25-32], i.e. to solve mental problems in a team. For example, in the foreign language classes (English in our case), group projects can be carried out when small groups are formed in which students perform special tasks or work together on a specific project. The main purpose of such groups is the identification and development of identified types of intelligence and teaching speaking.

According to the assesments, critical thinking of the students in experimental groups increased in comparance with control groups. Besides, the effectiveness of information perception, interest in learning process itself and desire to become a qualified specialist increased by the end of the course, so $88 \%$ of students realize that they can possess complex, in their opinion, skills (in our case, skills of English language communication), they will understand the importance of self-education and personal development.

The exercises must correspond to such a principle of training in the framework of MI theory as a joint creative activity. As a model, any text of fiction without dialogues, only the narrative can be used. The text must be visually accessible to students. As one of the elements of the exercise, it entered into the system of teaching non-philologal university students a foreign language. The effectiveness of this system is determined by the quantitative growth of indicators in the structure of teamwork skills and the dominance of one of them in each component of this skill.

In the cognitive aspect, this is knowledge of the psychology of communication in a group. In the value-motivational one, it is a positive attitude to the manifestation of initiative. In the praxeological aspect, it is the ability to act according to the accepted model of behavior in the organization, and in the reflective one, it is the ability to selfregulate the individual state and the condition of others [7, p. 208] To prove the effectiveness of this system, an analysis of summative and formative experiments was carried out.

So, the results of this work are as follows: the professional training of students of non-philologal university reaches the goal of a high level of teamwork skills, when, among the basic disciplines, the English language becomes a means of developing teamwork skills. The implementation of Multiple Intelligences theory contributes to the formation of the student's communicative qualities, as he learns a large number of new lexical units and grammatical constructions, the actualization of which occurs in the flow of speech. The ability to cooperative actions is acquired through joint creative activity, achieving a common goal and obtaining a result that is significant both for the group as a whole and for the individual student. As a result, the professional culture of the student, as the future competitive specialist, is significantly improved.

Conclusions. The implementation of the theory of Multiple Intellingences in the process of English learning to non-philologal university students has had a positive impact on learning the English language. Thus, the use of the theory of Multiple Intelligences allows the teacher to make each English lesson interesting and memorable, so the process of teaching and learning English is turning into an exciting lesson for both students and teachers.

We fully admit that teachers can object that this approach of education is not new; pedagogy and psychology have always paid attention to the differences in the special abilities of students and encouraged to take them into account. But here we can see a deeper approach. The whole Howard Gardner's theory is permeated with the idea that there is more than one way to teach what we consider important, and the theory of Multiple Intelligences can be a tool. In our opinion, the importance of the learning process, based on the theory of Multiple Intelligences, is focused on the development of student's mind and abilities. At the same time, the traditional learning process puts the mastery of the content of the program at the forefront, mainly through the verbal and logical/mathematical abilities of the student. Generally speaking, implementation of the Multiple Intellegences theory into the English language course at the non-philological university provides numerous opportunities for students to use and develop all types of intelligences and demonstrate their learning through new content and skills. This method of education offers a better understanding of students' learning preferences, so students realize that they can possess complex, in their opinion, skills (in our case, skills of foreign language communication), they will understand the importance of self-education and personal development. The perspectives of the study is to research the effects of implementation the Multiple Intelligences theory in the English language course syllabus. 


\section{References:}

1. Armstrong T. Multiple Intelligences in the classroom. Alexandria : ASCD, 2009. $246 \mathrm{p}$.

2. Baćik-Mirić N. Multiple Intelligences theory: A Milestone innovation in English Language Teaching at the University of NIŠ Medical School. P. 15-19. URL: https://core.ac.uk/download/pdf/26878788.pdf

3. Christison M. Teaching and learning through Multiple Intelligences. TESOL Journal. Washington, 1999. Vol 6. P. 10-14.

4. Gardner H. Frames of Mind: The Theory of Multiple Intelligences. New York : Basic Books, 1983. 440 p.

5. Gogoleva M. A., Kuznecova A. V. Learning Grammar in the Context of Multiple Intelligences theory. Scientific development trends and education. 2020. DOI: 10.18411/1j-02-2020-140.

6. Kincheloe Joe L., Nolan Kathleen etc. Multiple Intelligences Reconsidered. New York : Peter Lang, 2004.

7. Waterhouse L. Multiple Intelligences, the Mozart Effect, and Emotional Intelligence: A Critical Review. Educational Psychologist. 2006. Vol. 41. Issue 4. DOI: 10.1207/s15326985ep4104 1.

8. Nelson Kristen. Developing Students' Multiple Intelligences. Scholastic Professional Books, 1998. 160 p.

9. Tupper K. Entheogens and Existential Intelligence: The Use of Plant Teachers as Cognitive Tools. Canadian Journal of Education, 2002. № 27 (4). P. 499-516.

10. Андропова Е. Г. Использование теории множественности интеллекта на уроках английского языка. URL: $\quad$ https://nsportal.ru/shkola/inostrannye-yazyki/angliiskiyyazyk/library/2012/09/28/ispolzovanie-teoriimnozhestvennosti.

11. Антоненко Н. Є. Теорія множинного інтелекту Г. Гарднера як засіб диференціації іншомовної підготовки школярів. Наукові записки РДГУ. 2014. № 10 (53). С. 110-112.

12. Байсара Л. І. Множинність прояву видів інтелекту : конспект лекцій. Дніпро : РВВ ДНУ, 2010. 96 с.

13. Гоголева М. А. Использование теории множественного интеллекта в обучении английскому языку в неязыковом вузе. Научное обозрение: гуманитарные исследования. 2013. № 2. С. 25-32.

\section{КовалевсьКа О. В. ВПРОВАДЖЕННЯ ТЕОРЇ̈ МНОЖИННОГО ІНТЕЛЕКТУ У ПРОЦЕС ВИВЧЕННЯ АНГЛІЙСЬКОЇ МОВИ ДЛЯ СТУДЕНТІВ НЕФІЛОЛОГІЧНИХ СПЕЦАЛЬНОСТЕЙ}

Стаття присвячена розробиі нових дидактичних ідей, які безпосередньо пов'язані з розвитком теоретичної лінгвістики, філософії мови. У нам час філософія мови збагачується новими теоріями, що застосовуються в практиці вивчення англійської мови, але питання щзодо вибору найефективніших методів досить актуальне натепер. Увагу приділено впровадженню теорії множсинного інтелекту в прочесі вивчення англійської мови студентами нефілологічних спеціальностей. Впровадження теорії множинного інтелекту базується на філософії навчання, яка розглядає притаманний інтелект людини як сукупність рівнозначних інтелекту складових частин, які насамперед слід виявити, а потім розвинути в процесі навчання. Використання теорії множинного інтелекту у вивченні іноземної мови дозволяє зрозуміти, щяо мовна особливість надається всім студентам, а не лише для невеликої частини з них. Впровадження теорії множинного інтелекту справило позитивний вплив на вивчення англійської мови студентали нефілологічних спеціальностей. Результат експерименту свідчить про те, що застосування ицих методологічних розробок на заняттях англійської мови ефективне не лише для розвитку мовних навичок студента, але й для формування всебічно розвиненої творчості майбутніх фахівиів.

Теорія множинного інтелекту отримала всесвітнє визнання як одна з найбільш інноваційних теорій пізнання інтелекту людини. За умови правильного застосування в освітньому процесі, зокрема в прочесі вивчення англійської мови, теорія допоможе студентам повніше реалізувати свій потенціал i буде корисною для викладачів, щзоб знайти інновачійний підхід для навчання.

Ключові слова: філософія мови, нефілологічні спеціальності, студенти, теорія множинного інтелекту, прочес вивчення англійської мови. 